\title{
A infância de Jesus
}

\author{
RATZINGER, J., São Paulo, Ed. Planeta, 2012
}

(112 páginas)

Leonardo Agostini Fernandes

O texto original da presente obra foi escrito em alemão: Jesus Von Nazareth. Prolog. Die Kindheitschichten, publicado na Cidade do Vaticano pela Libreria Editrice Vaticana, mas lançado, simultaneamente, em outras oito línguas (croato, espanhol, francês, inglês, italiano, polonês, português do Brasil e de Portugal) aos 20 dias do mês de novembro de 2012. É o terceiro e último livro da série Jesus de Nazaré que foi apresentado ao Papa Bento XVI em uma audiência oficial pelos editores responsáveis pelas traduções. Está previsto que a obra seja traduzida, ainda, para outras vinte línguas e seja publicada em setenta e dois países.

Não se percebe uma metodologia exegética específica aplicada aos textos, mas se verifica uma clara opção metodológica: apresentar o conteúdo dos textos, deixando que a própria Sagrada Escritura ofereça os elementos necessários para a sua interpretação. Bento XVI aplica, assim, o princípio de que a Bíblia se explica com a Bíblia. Este princípio transparece no seu Magistério Petrino e se vislumbra pelo conhecimento e pelo amor que cultiva para com a Palavra de Deus. Mais do que falar sobre a Bíblia, Bento XVI sabe escutar o que a Bíblia tem a lhe dizer e a dizer para toda a Igreja, Corpo Místico do Verbo Encarnado, Jesus de Nazaré. Com isso, ele oferece ao seu interlocutor a possibilidade de "visitar" e "conhecer" numerosos textos do Antigo e do Novo Testamento. E Bento XVI não se limita a citar os textos, mas os articula, de forma catequética, no modo como apresenta, em cada parágrafo, o seu lúcido pensamento teológico sobre os textos.

Quando necessário, mas de forma sutil, o Papa cita algo que considera válido de um renomado estudioso. Desta feita, a lista das referências bibliográficas é breve, mas seleta, contemplando apenas 29 títulos. Também foram 
deixadas de lado as conjecturas e as meras especulações exegéticas. O que ainda não possui uma plausível explicação, o melhor a fazer é deixar a questão aberta, por respeito ao texto e por uma questão de fé, pois a Palavra de Deus é um mistério que respeita, também, os limites da razão e as reais condições do ser humano. Percebe-se, além disso, a sua postura acadêmica: Coisas antigas podem ser ditas não somente de novo, mas de um modo novo e de uma forma mais clara e objetiva para o povo sedento do bem, da justiça, da verdade, isto é, de Deus. O respeito pelo texto, enquanto Palavra de Deus encarnada na palavra humana, é o principal critério e a acertada regra hermenêutica utilizada por Bento XVI. Isso, ele já tinha deixado bem claro na Verbum Domini.

Bento XVI afirma, no prefácio, que este livro "não se trata de um terceiro volume, mas de uma espécie de pequena 'antecâmara' aos dois volumes anteriores sobre a figura e a mensagem de Jesus de Nazaré”. Nos dois primeiros capítulos, visto que existem vários elementos em comum, Mateus e Lucas são tratados conjuntamente. Já o terceiro e o quarto capítulos, devido aos traços particulares das escolhas bíblico-teológicas que foram feitas por Lucas (anúncio do anjo e visita dos pastores) e por Mateus (visita dos Magos e fuga para o Egito), são tratados separadamente, mas, quando há alusões, o diálogo entre os evangelistas, e do Papa com os textos, volta a acontecer. A cidade de Belém, no nascimento e nos primeiros anos da infância de Jesus, é um elemento comum entre Lucas e Mateus (p. 77-78). O epílogo não é uma conclusão para o livro, mas a reflexão sobre Jesus aos 12 anos no Templo. Esta última reflexão abre a perspectiva para o desdobramento que se seguirá na vida e na missão de Jesus de Nazaré, pelas quais se reconhecerá que Ele é o Filho de Deus e o Filho de Maria, Verdadeiro Deus e Verdadeiro Homem, como expressa a fé da Igreja.

"De onde és Tu?" (Jo 19,9). A pergunta sobre a origem de Jesus como questão acerca do seu ser e da sua missão é o título do primeiro capítulo elaborado em 10 páginas e sem subdivisões internas (p. 11-20). Este capítulo introduz a dinâmica fundamental que Bento XVI pretende imprimir no livro: responder à pergunta que Pilatos fez a Jesus durante o seu interrogatório. A pergunta pela origem de Jesus, feita por Pilatos, é racional, mas é, ao mesmo tempo, a indagação mais acentuada de uma pessoa que se vê confrontada com Jesus de Nazaré, pois deseja conhecer a respeito do seu ser e da sua missão. É a pergunta que continua inquietando a história da humanidade desde o nascimento de Jesus. O presente capítulo, magistralmente estruturado, começa e termina com o Evangelho Segundo São João. No corpo do capítulo, os Sinó- 
ticos são citados não de forma complementar, mas para introduzir a reflexão que brota de uma certeza: os relatos da infância tem sua razão de ser na dinâmica do mistério pascal. Esta dinâmica encontra-se presente ao longo de todos os capítulos. No fundo, a indagação pela origem de Jesus requer uma resposta condizente e, por isso, constitui a intenção dos evangelistas, que é a de revelar quem é Jesus, qual é a sua missão e como segui-lo.

As genealogias de Mateus e de Lucas, cada uma com características e objetivos teológicos próprios quer mostrar que Jesus é o Salvador Universal. João, no seu Prólogo, apresentou de forma explícita e grandiosa a resposta à pergunta "de onde" é Jesus, mas o fez ampliando, para definir a existência cristã, visto que a identidade do Mestre define a identidade dos discípulos. Quem crê em Jesus é como Jesus, não nasceu da carne e do sangue, mas nasceu de Deus. Bento XVI conclui que as genealogias não atestam somente a origem de Jesus, nascido da Virgem Maria por obra do Espírito Santo, mas atestam, também, a proveniência dos que nasceram, pela fé, de Deus (pp. 9-20). A pergunta pelo "De onde és Tu?" tem a ver com a profunda questão existencial do ser humano: "Quem sou eu?".

O anúncio do nascimento de João Batista e de Jesus é o título do segundo capítulo que ocupa 32 páginas e está articulado em 5 tópicos (p. 21-52). A questão central é a dúvida histórica, posta pela exegese moderna, quanto aos fatos narrados que, nos últimos anos, não foram vistos com grande interesse, mas praticamente foram tratados debaixo da categoria do mito.

Bento XVI prefere ocupar-se com a beleza literária dos textos e, por ela, encontra a razão para afirmar que "se narra uma história que explica a Escritura e, vice-versa, aquilo que quis dizer a Escritura, em muitos lugares, só agora se torna visível, por meio dessa história" (p. 22). Essa relação é ampliada: a Palavra de Deus explica os eventos e estes, por sua vez, desvelam a Palavra de Deus enquanto os textos se encontram envolvidos no mistério do amor de Deus. Nessa dinâmica, percebe-se a profunda relação que se estabelece entre o anúncio do nascimento de João Batista e o anúncio do nascimento de Jesus; uma relação que se articula entre promessa e cumprimento, entre continuidade e descontinuidade do Antigo com o Novo Testamento sem romper, porém, a unidade que existe entre esses dois momentos da Divina Revelação.

A marca característica dessa descontinuidade é a humildade com que a novidade acontece na história da humanidade: a kenosis de Deus, Uno e Trino, que torna possível as impossibilidades humanas, manifestando que chegou o momento da justiça ser estabelecida como salvação e como anúncio de alegria, 
sinais de que a graça de Deus é amor universal. Promessa e cumprimento tocam-se de forma divinamente humana e humanamente divina na proposta de Deus e na resposta de Maria, pelas quais o Verbo se fez carne e habitou entre nós. Também está presente na vida de José que, pela fé, vence na justiça e pela justiça o drama da sua existência diante do mistério que acontece na vida da prometida esposa. A kenosis de Deus reflete-se e opera na kenosis de Maria e de José que acolhem a kenosis do mistério da Encarnação do Verbo Divino e, com ela, todas as suas consequências da futura kenosis da Igreja e de seus membros.

À beleza literária dos textos une-se a riqueza da narrativa no envolvimento que acontece entre o evangelista, que faz o papel do narrador, e das personagens que atuam em cada cena. Por meio delas, o interlocutor pode perceber e conhecer a dinâmica da fé, da esperança e do amor que alimenta a vida do Papa, enquanto provoca a vida do interlocutor, que se sente chamado, pela narrativa, a perceber o divino em ação na capacidade do seu discernimento. Lucas e Mateus referem-se à concepção e ao nascimento de Jesus destacando, cada um, perspectivas teológicas distintas, mas que se completam. Para o Papa, os textos do Antigo Testamento se tornam, nos Evangelhos, textos cristológicos, fontes para a fé que a Igreja definirá e que, também, vai defini-la.

Se a José, em sonho, fora revelado pelo anjo uma postura: "José, filho de Davi, não temas receber Maria, tua mulher, pois o que nela foi gerado vem do Espírito Santo" (Mt 1,20); ao Papa e a cada leitor dos Evangelhos está sendo dito: "Filho(a) de Deus, não temas receber as Sagradas Escrituras, pois o que nela está contido vem do Espírito Santo". E assim, cada um, se encontra envolvido, novamente, com a força e com o mistério da Encarnação de Deus.

É contundente e perspicaz uma afirmação: "O homem é um ser relacional; se fica perturbada a primeira relação fundamental do homem - a relação com Deus -, então nada mais pode estar verdadeiramente em ordem” (p. 43). Quando se aposta mais na força política do que na força da fé, o medo torna-se uma constante na vida do ser humano. Com isso, não se realiza a ação presente de Deus expressa no nome Yehoshua (“o Senhor é salvação") e no nome Emanuel (Deus está conosco) que denominam a presença e o agir do Deus Filho Encarnado, que é a visibilidade e a imagem do Deus invisível entre os seres humanos.

O Papa não teme citar e até criticar as posturas exegéticas que esvaziaram os textos do seu significado, pois a dissemelhança presente entre as narrativas da infância de Jesus e as narrativas extra-bíblicas superam qualquer traço semelhante que possa se ver como sendo simplesmente narrativas paralelas 
aos textos do Egito e da Mesopotâmia. "As narrações em Mateus e Lucas não são formas mais desenvolvidas de mitos. Segundo a sua noção de fundo, estão solidamente colocadas na tradição bíblica de Deus Criador e Redentor. Mas, quanto ao seu conteúdo concreto, provêm da tradição familiar; são uma tradição transmitida que conserva aquilo que aconteceu" (p. 49). E ainda: "O mistério do início iluminava o que vinha a seguir e, vice-versa, a fé em Cristo já desenvolvida ajudava a compreender o início, a sua densidade de significado. Assim se desenvolveu a cristologia” (p. 50).

O segundo capítulo, construído em forma de aparentes contrastes, serve para mostrar que o Plano de Deus ultrapassa a compreensão da razão humana, mas é real porque, inserido na história do povo eleito, feito mediador para todos os povos, revela que para Deus nada é impossível, diante do "sim", possível e livre, do ser humano obtido em Maria e aceito por José. É o sim que supera toda a incapacidade humana. O centro da mensagem ecoa, então, no "Não temas!". Essa mensagem, sem retirar a dureza da realidade, proporciona e "requer uma fé excepcionalmente corajosa" de quem viveu os acontecimentos e de quem se encontra diante deles pela leitura e meditação dos textos que os narram. No fim, o Papa deixa claro que a fé na concepção e na ressurreição são pedras de toque, pois não são ações de Deus na ideia humana, mas na matéria. O milagre é histórico. Deus é Deus não só porque pode ser pensado, mas porque pode se encarnar e habitar no meio dos homens para salvá-los.

O nascimento de Jesus em Belém é o título do terceiro capítulo elaborado em 23 páginas e articulado em 3 tópicos (p. 53-75). De início, o Papa enfrenta as dúvidas quanto à historicidade dos fatos narrados segundo o evangelista Lucas. Diante da dificuldade de se obter uma exatidão, fica como critério que há nos relatos conteúdos essenciais dignos de crédito. Importa lembrar que "Lucas estava mais perto das fontes e dos acontecimentos do que nós, apesar de toda a erudição histórica, o possamos pretender" (p. 57). Dado histórico e dado teológico estão unidos e entrelaçados, não há como separá-los sem sérios prejuízos tanto para um como para o outro. É suficiente, porém, para a fé permanecer nas fontes utilizadas e elaboradas por Lucas, mas não se deve esquecer um princípio que auxilia essas fontes: "muitas vezes as tradições locais são uma fonte mais atendível que as informações escritas" (p. 60).

Poucas vezes o Papa se detém diante de problemas exegéticos e de tradução, mas não se nega a tratar do problema subjacente à tradução da segunda parte do anúncio do anjo aos pastores que aparece como: "aos homens de boa vontade", "homens de sua graça" e "homens que ele ama". Ele não segue ne- 
nhuma dessas opções de tradução e prefere o sentido literal que está no texto: "homens do [seu] agrado", visto que guarda a razão do mistério e da revelação de que Jesus é o homem que agrada a Deus por ser obediente e viver totalmente voltado para o Pai, pois nele o Pai é totalmente glorificado. A kenosis volta a ser tratada para confrontar a grandeza do Império Romano diante do sinal da grandeza de Deus manifestada na pobreza de como o seu Filho Unigênito veio a este mundo. Nisto já se encerra a base para se falar que "a teologia da glória está indivisivelmente ligada à teologia da cruz” (p. 73).

A reflexão, que Bento XVI realiza sobre as três partes do terceiro capítulo, acontece com grande vivacidade, seriedade e entusiasmo, bem de acordo com a índole dos textos que narram o ambiente histórico sobre o qual Lucas enquadrou o nascimento de Jesus e a sua apresentação no templo. Elemento essencial dessa vivacidade fica por conta das personagens e de suas ações. Estas entram em cena e interagem, fazendo com que a presença e a ação de Deus sejam percebidas como manifestação da verdade salvífica a ser comunicada.

Os magos do Oriente e a fuga para o Egito é o título do quarto capítulo elaborado em 24 páginas e articulado em sete tópicos. É o capítulo mais subdividido do livro (p. 77-100). Bento XVI se serve da figura de Balaão, conhecida no Antigo Testamento, para admitir que circulava, fora da Bíblia e da Palestina, uma profecia não judia sobre o nascimento de um rei, salvador universal, ligado ao sinal de esperança refletido na estrela de Judá (cf. Nm 24,17).

Ao verificar o sentido do termo mago, opta pelo âmbito da sabedoria religiosa e filosófica. Esta sabedoria é a força que põe os magos a caminho de Israel, seguindo a estrela que viram no Oriente. São homens dispostos a ir além do que são e do que conhecem, pois querem a verdade. Os magos "representam o caminho das religiões para Cristo, bem como a autossuperação da ciência rumo a Ele" (p. 82). Os magos tornaram-se reis, na tradição cristã, graças ao que está dito no S1 72,10 e em Is 60; com eles, pode-se dizer, a composição do presépio ficou completa: pastores, ovelhas, boi, asno, reis, camelos e dromedários. São pobres e ricos, são os que vêm de perto e os que vêm de longe. Os magos "inauguram uma procissão que percorre a história inteira". Eles se inclinam diante do Menino Jesus. Os magos representam "o movimento das religiões e da razão humana ao encontro com Cristo" (p. 83). Isso acontece porque "não é a estrela que determina o destino do Menino, mas o Menino que guia a estrela", atraindo-a na sua direção, para que vejam no sinal do céu a glória que aconteceu na terra.

Antes, porém, de chegarem a Belém, os magos tiveram que passar por Herodes, pelos chefes, pelos sacerdotes, pelos escribas de Israel e por Jeru- 
salém, a fim de que passassem pela mediação do povo eleito e de suas Sagradas Escrituras. Por isso a estrela desapareceu! Não basta conhecer e chegar ao local do nascimento, é preciso saber a "interpretação teológica do lugar e do acontecimento" (p. 89). Aqui, sutilmente, o Papa não se contém e manda um recado para os exegetas que muitas vezes estão mais preocupados com a historicidade dos fatos do que com a busca pela interpretação e pelo valor histórico-teológico presente nos textos.

Depois disso, a estrela volta a brilhar. "A criação, interpretada pela Escritura, volta a falar ao homem" (p. 89). O coração, então, se enche de alegria! A interpretação sobre a chegada dos magos à casa, onde se encontra o Menino Rei com sua mãe, não revela grandes novidades, mas chama a atenção de Bento XVI não ter encontrado, ad intra e ad extra da Bíblia, uma explicação para a ausência de José na cena.

Todavia, São José entra em cena, novamente como protagonista, no episódio sobre a fuga para o Egito e o regresso à Terra de Israel. O que motivou Mateus a aproximar esse episódio de Jesus à história de Moisés, segundo Bento XVI, não tem tanto a ver com a haggadá de Moisés, mas com a compreensão de que, com Jesus, a humanidade inteira, e não só Israel, terá a oportunidade de experimentar o êxodo definitivo. "Jesus, o verdadeiro Filho, em sentido profundo, sai Ele mesmo para o 'exílio' a fim de nos trazer a todos da alienação para a casa” (p. 94). Esta certeza de fé ajuda a compreender o martírio dos santos inocentes, mas somente com a ressurreição de Jesus é que o consolo, de fato, acontecerá, pois revelará que eles não morreram em vão. A comunicação divina com São José acontece, mais uma vez, em forma de sonho "e assim aparece novamente como aquele que escuta e é capaz de discernimento, como aquele que é obediente e ao mesmo tempo decidido e criteriosamente pragmático" (p. 95).

A questão central do último capítulo diz respeito às dúvidas quanto ao valor histórico dos dois capítulos sobre a narrativa da infância de Jesus em Mateus. A posição de Bento XVI é categórica: não há razões suficientes para se duvidar das intenções de Mateus e dos fatos narrados, mesmo considerando que estes foram reelaborados de forma teológica para que o mistério de Jesus fosse compreendido de forma mais profunda.

Jesus aos 12 anos no Templo é o título do epílogo contendo, apenas, 6 páginas (p. 101-106). De acordo com Bento XVI, trata-se de um precioso fragmento da tradição testemunhado por São Lucas. Neste episódio, "transparece de modo singular o mistério de Jesus" (p. 101), que possui, próprio 
porque é Filho de Deus, uma liberdade radical e uma fidelidade igualmente radical que supera qualquer experiência religiosa e qualquer compreensão humana. "As palavras de Jesus não cessam jamais de serem maiores que a nossa razão; superam, sempre de novo, a nossa inteligência" (p. 104). Maria e José disto são testemunhas! Por isso, uma correta exegese deve ser humilde e capaz de respeitar essa grandeza; quando respeita, submete-se, e quando se submete, acredita e cresce na sua direção. O mistério que transparece nesse episódio atesta que o Filho Unigênito se reconhece no seu Pai e que o Pai se reconhece no seu Filho.

A primeira tiragem, logo de início, chega a um milhão de cópias. Assim, a obra já começa como um best-seller. Mais do que apostar nas vendas, o Papa aposta no interesse dos fiéis e dos homens que agradam a Deus pela redescoberta, nas proximidades do Natal, dos chamados "evangelhos da infância de Jesus", a fim de que a sua mensagem chegue integralmente aos distantes e aos céticos de um mundo em crise e que continua clamando por salvação.

Leonardo Agostini Fernandes

Doutor em Teologia Bíblica pela Universidade Gregoriana de Roma Professor e Diretor do Departamento de Teologia da PUC-Rio

Resenha Recebida em 28/02/2012 Resenha Aprovada em 30/03/2012 